\title{
A SH3_5 Cell Anchoring Domain for Non-recombinant Surface Display on Lactic Acid Bacteria
}

\author{
Pei Kun Richie Tay, Pei Yu Lim and Dave Siak-Wei Ow* \\ Microbial Cells Group, Bioprocessing Technology Institute, Agency for Science, Technology and Research (A*STAR), \\ Singapore, Singapore
}

\section{OPEN ACCESS}

Edited by:

Mingfeng Cao,

University of Illinois at

Urbana-Champaign, United States

Reviewed by:

Aleš Berlec

Institut JoŽef Stefan (IJS), Slovenia Muralikannan Maruthamuthu,

Purdue University, United States

*Correspondence:

Dave Siak-Wei Ow

dave_ow@bti.a-star.edu.sg

Specialty section:

This article was submitted to

Synthetic Biology,

a section of the journal

Frontiers in Bioengineering and

Biotechnology

Received: 06 October 2020

Accepted: 30 December 2020

Published: 27 January 2021

Citation:

Tay PKR, Lim PY and OW DS-W (2021) A SH3_5 Cell Anchoring

Domain for Non-recombinant Surface

Display on Lactic Acid Bacteria.

Front. Bioeng. Biotechnol. 8:614498.

doi: 10.3389/fbioe.2020.614498
Lactic acid bacteria $(\angle A B)$ are a group of gut commensals increasingly recognized for their potential to deliver bioactive molecules in vivo. The delivery of therapeutic proteins, in particular, can be achieved by anchoring them to the bacterial surface, and various anchoring domains have been described for this application. Here, we investigated a new cell anchoring domain (CAD4a) isolated from a Lactobacillus protein, containing repeats of a SH3_5 motif that binds non-covalently to peptidoglycan in the LAB cell wall. Using a fluorescent reporter, we showed that C-terminal CAD4a bound Lactobacillus fermentum selectively out of a panel of LAB strains, and cell anchoring was uniform across the cell surface. Conditions affecting CAD4a anchoring were studied, including temperature, $\mathrm{pH}$, salt concentration, and bacterial growth phase. Quantitative analysis showed that CAD4a allowed display of $10^{5}$ molecules of monomeric protein per cell. We demonstrated the surface display of a functional protein with superoxide dismutase (SOD), an antioxidant enzyme potentially useful for treating gut inflammation. SOD displayed on cells could be protected from gastric digestion using a polymer matrix. Taken together, our results show the feasibility of using CAD4a as a novel cell anchor for protein surface display on LAB.

Keywords: lactic acid bacteria, cell anchoring domain, bacteria surface display, bacteria protein delivery, superoxide dismutase, probiotics

\section{INTRODUCTION}

Microbial cell-surface display has a wide range of biotechnological and industrial applications. It can be used to screen protein and peptide libraries in directed evolution, epitope mapping and drug discovery (Rockberg et al., 2008; Hudson et al., 2012; Fleetwood et al., 2013; Robert and Gouet, 2014). Microbes displaying proteins are also useful as remedial biosorbents (Tang et al., 2014; Hui et al., 2018; Maruthamuthu et al., 2018), biosensors (Han et al., 2018; Park, 2020), whole-cell biocatalysts (Pontes et al., 2012), and as vaccines and delivery vectors for therapeutics (Cano-Garrido et al., 2015; Plavec and Berlec, 2019). Lactic acid bacteria (LAB) are a heterogeneous group of Gram-positive bacteria, commonly of the genera Lactococcus, Lactobacillus, Streptococcus, Pediococcus, and Leuconostoc. They have a long history as components of fermented foods and are thus considered GRAS ("generally regarded as safe" per U.S. Food and Drug Administration). They are used industrially in feed and food fermentation, and in the production of various fine chemicals (Mora-Villalobos et al., 2020). Many lactobacilli also colonize mucosa in humans and animals, forming part of the intestinal and vaginal microbiomes, and probiotic strains of Lactobacillus have been identified that confer health benefits to the host (Gill and Prasad, 2008; Walter, 2008). These characteristics make LAB valuable candidates for protein display in numerous industrial and biomedical applications. 
LAB displaying enzymes can be used as biocatalysts for industrial processes. Nguyen et al. displayed $\beta$-mannanase on the surface of Lactobacillus plantarum for the production of manno-oligosaccharides, a class of prebiotic oligosaccharides (Nguyen et al., 2019). Similarly, Pham et al. displayed dimeric $\beta$-galactosidases on $L$. plantarum for lactose conversion and production of galacto-oligosaccharides (Pham et al., 2019). In both cases, the bacterial catalysts could be used for multiple rounds of bioconversion. Other groups displayed cohesins on L. plantarum and Lactococcus lactis to assemble multi-enzyme cellulosomal complexes for the degradation of complex polymers (Wieczorek and Martin, 2012; Stern et al., 2018). Surface display could also be used to introduce substrate-binding domains on LAB to enable cell immobilization on solid supports for continuous bioprocessing, as has been demonstrated for L. lactis displaying a chitin-binding domain (Simşek, 2014).

$\mathrm{LAB}$ have also been investigated for therapeutic use, for instance, to treat metabolic and gastrointestinal diseases. Companies like Aurealis Pharma and Precigen ActoBio are developing "live biotherapeutics" using engineered strains of Lactococcus lactis that secrete therapeutic proteins and peptides in the oral and gastrointestinal tract. Anchoring these therapeutic entities to the bacteria surface could provide protection against proteolysis during gastrointestinal transit (Mao et al., 2016). Proteins that have been successfully displayed on $L$. lactis include $\beta$-galactosidase to manage lactose intolerance; an insulin analog (SCI-59) to manage diabetes; and the thrombolytic agent subtilisin QK-2 (Mao et al., 2016, 2017; Yin et al., 2018). Various protein domains that block pro-inflammatory cytokines and chemokines have been also displayed on LAB to treat inflammatory bowel disease (IBD) (Kosler et al., 2017; Škrlec et al., 2017; Plavec et al., 2019). Škrlec et al. displayed a pentadecapeptide $\mathrm{BPC}-157$ to reduce the production of reactive oxygen species (ROS) to moderate gut inflammation (Skrlec et al., 2018). Protein display on LAB can also be used to develop bacterial vaccine vectors. Here the innate immunogenicity of certain probiotic strains may obviate the need for adjuvants. Lactic acid bacteria engineered to display antigens from influenza A, pneumococcus, Mycobacterium tuberculosis, and SARS-CoV have shown efficacy as mucosal vaccines against their respective viral and bacterial pathogens in animal models (Lee et al., 2006; Hernani Mde et al., 2011; Chowdhury et al., 2014; Mustafa et al., 2018). LAB can also be developed into efficient vectors for DNA delivery through the surface display of targeting proteins that directly interact with host epithelial or immune cells (Pontes et al., 2012; Liu et al., 2019).

To enable surface display, a protein or peptide is fused to an anchoring domain that binds to the LAB cell wall. Such anchoring domains may be covalently linked to a cell wall component, or they may bind non-covalently. Examples of covalent anchors include lipoproteins like BmpA and PrsA (Fredriksen et al., 2012; Zadravec et al., 2014); transmembrane proteins like PgsA (Narita et al., 2006; Lei et al., 2011); and more commonly, LPXTG domains derived from the streptococcal M6 protein or the L. plantarum Lp_2578 protein, which are anchored to peptidoglycans by cell wall sortases (Dieye et al.,
2001; Fredriksen et al., 2010). Bacteria are usually genetically modified for covalent display, but the use of GM bacteria raises safety concerns and may encounter lower consumer acceptance and more severe regulatory scrutiny, especially when used in food or pharmaceutical preparations. Non-covalent anchoring strategies avoid the use of recombinant bacteria as hosts for protein display. Proteins containing non-covalent anchoring domains can be produced in an expression strain, then anchored in trans to a wild-type (non-GM) host LAB strain. Another advantage of this approach is that protein production is not limited by the biosynthetic capabilities of the host bacterium, and can undergo further post-translational modifications prior to surface anchoring.

The success of a non-covalent cell surface display system depends on choosing an appropriate anchoring motif for the target protein and host cell. Each anchoring domain has a different capacity for protein display, and can be highly selective of its target LAB. While several non-covalent binding domains have been identified, only a few have been applied for protein surface display. These include: lactobacillal S-layer homology domains (Åvall-Jääskeläinen et al., 2002; Hu et al., 2011); WxL (Brinster et al., 2007), SH3 (Plavec et al., 2019); CW_1 (Plavec et al., 2019) and LysM (Raha et al., 2005; Hu et al., 2010; Ravnikar et al., 2010; Xu et al., 2011). Although many of these domains have known binding partners, the mechanism of binding is still ambiguous for some (Desvaux et al., 2018). The LysM domain from the lactococcal protein AcmA is a commonly used noncovalent anchor for LAB surface display (Steen et al., 2005; Bosma et al., 2006; Ravnikar et al., 2010). New anchoring motifs are constantly being sought to target a wide range of LAB, and to allow surface display of different proteins on the same cell. The bacterial SH3 type 5 motif (SH3_5; Pfam PF08460) is known to bind cell wall peptidoglycans in Gram-positive bacteria (Becker et al., 2009; Mitkowski et al., 2019). It contains 60-65 amino acids and is mainly found among Firmicutes, especially of the Streptococcus and Lactobacillus genera (Desvaux et al., 2018). A recent report described the use of a lactococcal phage SH3_5 motif for surface display in L. lactis (Plavec et al., 2019). Nonetheless, SH3_5 has not been widely investigated for bacterial protein display. The goal of the present study was to test a newlyidentified anchoring domain (CAD4a) containing SH3_5 repeats for heterologous protein display on LAB. The CAD4a domain was isolated from an L. plantarum protein. We appended this domain to two proteins-a fluorescent reporter and a dimeric enzyme - and examined functional display on LAB, as well as conditions for optimal anchoring, and resistance of the anchored proteins to gastric digestion.

\section{MATERIALS AND METHODS}

\section{Bacterial Strains, Culture Conditions, and Plasmid Assembly}

The bacteria strains and plasmids used in this study are listed in Table 1. Cloning was performed in E. coli Turbo and proteins were expressed in E. coli BL21(DE3) as detailed in the next section. E. coli was selected on LB agar supplemented with 
TABLE 1 | Bacterial strains and plasmids used in this study.

\begin{tabular}{|c|c|c|}
\hline & Feature & Source \\
\hline \multicolumn{3}{|l|}{ Strains } \\
\hline E. coli Turbo & 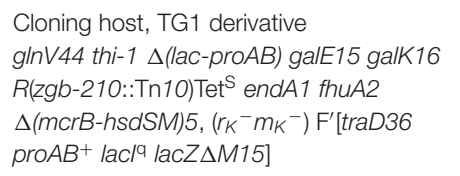 & NEB \\
\hline $\begin{array}{l}\text { E. coli } \\
\text { BL21(DE3) }\end{array}$ & $\begin{array}{l}\text { Expression host, E. coli str. B } \\
\mathrm{F}^{-} \text {ompT gal dcm lon hsdS } S_{B}\left(r_{B}{ }^{-} m_{B}{ }^{-}\right) \\
\lambda(\mathrm{DE} 3[\text { lacl lacUV5-T7p07 ind1 sam7 } \\
\text { nin5]) }\left[\text { malB }^{+}\right]_{\mathrm{K}-12}\left(\lambda^{S}\right)\end{array}$ & $\begin{array}{l}\text { Thermo } \\
\text { Fisher }\end{array}$ \\
\hline $\begin{array}{l}\text { Lactococcus } \\
\text { lactis NZ9000 }\end{array}$ & $\begin{array}{l}\text { Binding host, MG1363 derivative } \\
\text { pepN::nisRK }\end{array}$ & MoBiTec \\
\hline $\begin{array}{l}\text { Lactobacillus } \\
\text { casei } 393\end{array}$ & Binding host, wild type & ATCC \\
\hline $\begin{array}{l}\text { Lactobacillus } \\
\text { fermentum } \\
14931\end{array}$ & Binding host, wild type & ATCC \\
\hline $\begin{array}{l}\text { Lactobacillus } \\
\text { plantarum } \\
8014\end{array}$ & Binding host, wild type & ATCC \\
\hline $\begin{array}{l}\text { Lactobacillus } \\
\text { rhamnosus GG }\end{array}$ & Binding host, wild type & Lesaffre \\
\hline \multicolumn{3}{|l|}{ Plasmids } \\
\hline pET22b & $\mathrm{P}_{\mathrm{T} 7}, \mathrm{Amp}^{\mathrm{R}}$, lacl gene, $\mathrm{N}$-terminal pelB seq & Novagen \\
\hline pET22b-Sirius & His-tagged Sirius & This study \\
\hline $\begin{array}{l}\text { pET22b-Sirius- } \\
\text { CAD4a12 }\end{array}$ & $\begin{array}{l}\text { 12-residue spacer between Sirius and } \\
\text { CAD4a }\end{array}$ & This study \\
\hline $\begin{array}{l}\text { pET22b-Sirius- } \\
\text { CAD4a24 }\end{array}$ & $\begin{array}{l}\text { 24-residue spacer between Sirius and } \\
\text { CAD4a }\end{array}$ & This study \\
\hline $\begin{array}{l}\text { pET22b-Sirius- } \\
\text { CAD4a36 }\end{array}$ & $\begin{array}{l}\text { 36-residue spacer between Sirius and } \\
\text { CAD4a }\end{array}$ & This study \\
\hline pET22b-SOD & His-tagged SOD & This study \\
\hline $\begin{array}{l}\text { pET22b-SOD- } \\
\text { CAD4a12 }\end{array}$ & $\begin{array}{l}\text { 12-residue spacer between SOD and } \\
\text { CAD4a }\end{array}$ & This study \\
\hline $\begin{array}{l}\text { pET22b-SOD- } \\
\text { CAD4a24 }\end{array}$ & $\begin{array}{l}\text { 24-residue spacer between SOD and } \\
\text { CAD4a }\end{array}$ & This study \\
\hline $\begin{array}{l}\text { pET22b-SOD- } \\
\text { CAD4a36 }\end{array}$ & $\begin{array}{l}\text { 36-residue spacer between SOD and } \\
\text { CAD4a }\end{array}$ & This study \\
\hline
\end{tabular}

$100 \mu \mathrm{g} / \mathrm{ml}$ carbenicillin. Lactic acid bacteria were grown in static, unaerated MRS broth (Sigma-Aldrich) at $37^{\circ} \mathrm{C}$.

Supplementary Table 1 lists the primers and synthetic gene fragments used in this study. Primers and gene fragments were synthesized by Integrated DNA Technologies (USA). Gibson assembly was used to construct all plasmids. The pET22b plasmid was linearized with primers $\mathrm{F} 1$ and R1, and assembled with fragment G10 to give pET22b-Sirius. pET22b-Sirius was linearized with primers $\mathrm{F} 1$ and either R7 or R6, to give pET22bSi-CAD4a12 and -Si-CAD4a24, respectively, after assembly with gene fragment G5. CAD4a was subcloned from pET22b-SiCAD4a24 using primers F15 and R5, then assembled with pETSirius linearized with F1 and R26, to give pET22b-Si-CAD4a36.

For the SOD constructs, G29 was amplified with primers F18 and R37, and pET22b-Sirius linearized with primers F1 and R4. Both fragments were then assembled to give pET22b-SOD.
pET22b-SOD was linearized with primers F1 and either R24 or R25, to give pET22b-SOD-CAD4a12 and -SOD-CAD4a24, respectively, after assembly with gene fragment G5. CAD4a was subcloned from pET22b-Si-CAD4a24 with primers F15 and R5, then assembled with pET-SOD linearized with F1 and R27, to give $\mathrm{pET} 22 \mathrm{~b}-\mathrm{SOD}-\mathrm{CAD} 4 \mathrm{a} 36$.

\section{Protein Expression}

Overnight E. coli BL21(DE3) cultures were diluted 1:100 in Terrific Broth and grown to optical density $\mathrm{OD}_{600} \sim 0.8$. At that point, the temperature was reduced to $20^{\circ} \mathrm{C}$ and sorbitol was added to a concentration of $0.4 \mathrm{M}$. Sorbitol was added only for expression of CAD4a protein conjugates, to reduce protein aggregation. Expression was induced with $0.2 \mathrm{mM}$ IPTG and allowed to proceed for $6 \mathrm{~h}$ at $20^{\circ} \mathrm{C}$. Cells were then pelleted at $4,000 \mathrm{~g}$ for $10 \mathrm{~min}$, resuspended in Tris buffer (50 mM Tris, $0.3 \mathrm{M}$ $\mathrm{NaCl}, \mathrm{pH}$ 8), and subjected to one freeze-thaw cycle before lysis on ice with a probe sonicator (Microson XL2000, $10 \mathrm{~s} \mathrm{ON,} 10 \mathrm{~s}$ OFF, 8 cycles). The lysate was pelleted at $12,000 \mathrm{~g}$ for $30 \mathrm{~min}$ at $4{ }^{\circ} \mathrm{C}$, and separated on Ni-NTA resin (Qiagen, USA) in a PD-10 column. His-tagged protein was eluted with $200 \mathrm{mM}$ imidazole, then concentrated and buffer-exchanged into $1 \times \mathrm{PBS}(\mathrm{pH} 7.4)$ and stored at $4^{\circ} \mathrm{C}$ until use.

\section{SDS-PAGE and Western Blot}

Protein concentrations were determined using Bradford reagent (Biorad). Protein samples were analyzed on NuPAGE 4-12\% BisTris gels (Life Technologies), following manufacturer's protocols. Gels were stained with InstantBlue (Expedeon) or transferred onto nitrocellulose membranes using the semi-dry method at $20 \mathrm{~V}$ for $20 \mathrm{~min}$ (Trans-Blot, Bio-Rad). The membrane was washed with TBST $(1 \times$ TBS, $0.1 \%$ Tween 20$)$, blocked with $5 \%$ $\mathrm{w} / \mathrm{v}$ non-fat dry milk in TBST for $1 \mathrm{~h}$ at room temperature, then exposed to a 1:10,000 dilution of HRP-conjugated anti-His antibody (Merck) for $1 \mathrm{~h}$ at room temperature before detection with Clarity Western ECL Blotting Substrate (Bio-Rad) using the manufacturer's protocol. Gel images were acquired on a ChemiDoc MP imaging system (Bio-Rad), and blots were imaged on an ImageQuant LAS 500 imager (GE Healthcare).

\section{Anchoring of Sirius-CAD4a to Lactic Acid Bacteria}

Lactobacillus casei, L. fermentum, L. plantarum, L. rhamnosus, and Lactococcus lactis were grown to mid-log $\left(\mathrm{OD}_{600} 0.8-\right.$ 1.2) or stationary phase (overnight culture), washed once with $10 \%$ glycerol, then resuspended in a 50:50 mix of MRS and $20 \%$ glycerol, aliquoted, and frozen at $-80^{\circ} \mathrm{C}$ to obtain stocks for subsequent cell binding studies. Except where stated otherwise, the following protocol was used for binding studies. Frozen log-phase cells were thawed and washed twice with binding buffer $(1 \times \mathrm{PBS}, \mathrm{pH} 5)$, diluted to $\mathrm{OD}_{600}=1.5$, and resuspended in $75 \mu \mathrm{l}$ of binding buffer containing $2 \mu \mathrm{M}$ of Sirius$\mathrm{CAD} 4 \mathrm{a} 12$. The mixture was incubated for $1.5 \mathrm{~h}$ at $37^{\circ} \mathrm{C}$ with periodic mixing, then pelleted and washed twice with the same binding buffer before transfer to a black 96-well-polystyrene plate for fluorescence measurement. Cell-associated fluorescence was measured on a spectrophotometer (Tecan, USA) with 
excitation at $355 \mathrm{~nm}$ and emission at $424 \mathrm{~nm}$. The background fluorescence of the cells was subtracted to obtain a reading in relative fluorescence units (RFU). All studies were performed in triplicate. Cell imaging was performed on a Nikon Eclipse Ni-U microscope using a DAPI filter and $60 \times$ oil immersion lens.

\section{Influence of Cell Growth Phase, Salt Concentration, $\mathrm{pH}$, and Binding Temperature on CAD4a Anchoring}

The effect of cell growth phase on CAD4a binding capacity was investigated with frozen L. fermentum at mid-log and stationary phase. The influence of salt concentration on CAD4a binding to L. fermentum was tested using phosphate buffer $(\mathrm{pH} 5)$ supplemented with $\mathrm{NaCl}$ to final concentrations of $0.05,0.1,0.15$, $0.2,0.3,0.4 \mathrm{M} \mathrm{NaCl}$. The influence of $\mathrm{pH}$ was evaluated using PBS at $\mathrm{pH} 4.5,5,5.5,6,6.5,7,8$, and 9. The effect of binding temperature was tested at 25,30 , and $37^{\circ} \mathrm{C}$, with half-hourly timepoints up to $3 \mathrm{~h}$. Protein concentration used was $2 \mu \mathrm{M}$ in these studies; protein binding and fluorescence measurement were carried out as described above.

\section{Effect of Cell Pre-Treatment on CAD4a Anchoring}

Frozen $L$. fermentum aliquots were treated with either $5 \mathrm{M} \mathrm{LiCl}$ or $10 \% \mathrm{v} / \mathrm{v}$ trichloroacetic acid (TCA) at $37^{\circ} \mathrm{C}$ with shaking for 1 h. Cells were washed twice with $\mathrm{pH} 7 \mathrm{PBS}$ and once with $\mathrm{pH} 5$ PBS before binding experiments.

\section{Binding Capacity of CAD4a on $L$. fermentum}

Fresh overnight cultures of $L$. fermentum were washed twice with binding buffer ( $\mathrm{pH} 5 \mathrm{PBS}$ ), diluted to $\mathrm{OD}_{600}=1.5$, and incubated with $70 \mu \mathrm{l}$ of various concentrations of SiriusCAD4a12 $(0,0.5,1,2,3,4,5 \mu \mathrm{M})$. This was used to set up a standard curve to correlate RFU to protein concentration in the presence of cells. Subsequently, cell mixtures were pelleted and cell fluorescence determined as described above. All data points represent the average of at least three experiments. Nonlinear regression analysis was used to fit the binding data to the Langmuir adsorption model to determine $B_{\max }$, the protein concentration at saturation. Assuming that the distribution of the anchored protein was uniform across the entire cell population, we calculated the average binding capacity per cell using $B_{\max }$ and the standard curve.

\section{Influence of Spacer Length on Activity of Surface-Displayed Superoxide Dismutase}

Superoxide dismutase (SOD) from Potentilla atrosanguinea (Kumar et al., 2012) was engineered with C-terminal CAD4a and three different spacer lengths (12-, 24-, and 36-residues) between the enzyme and anchoring domain. A flexible (GGSG) $x$ spacer was used, where $x=3$ for the 12-residue spacer, $x=6$ for the 24 -residue spacer, and $x=9$ for the 36 -residue spacer. Proteins were expressed in E. coli, and protein binding was performed with frozen log-phase L. fermentum as described above. After washing, cells were resuspended in binding buffer for the SOD activity assay.

\section{Superoxide Dismutase Activity Assay}

SOD activity assay was done using a commercial SOD kit (Sigma-Aldrich 19160) according to the manufacturer's protocol. The average gradient over the first $10 \mathrm{~min}$ (linear range) from triplicates was used to calculate the activity for each sample.

\section{Cell Encapsulation}

Cell encapsulation was adapted from a previously-described protocol (Nualkaekul et al., 2012). Low-viscosity alginate (SigmaAldrich) was prepared as a $6 \% \mathrm{w} / \mathrm{v}$ stock in distilled water. Low molecular weight chitosan (Sigma-Aldrich) was dissolved in $0.1 \mathrm{M}$ acetic acid to a concentration of $0.5 \% \mathrm{w} / \mathrm{v}$, and the final $\mathrm{pH}$ adjusted to 5 . Fresh overnight cultures of L. fermentum were washed twice with binding buffer ( $\mathrm{pH} 5$ PBS), diluted to $\mathrm{OD}_{600}=1.5$, and incubated with $2 \mu \mathrm{M}$ SOD-CAD4a12 or SOD-CAD4a36. After washing, $2 \mathrm{ml}$ of cells was resuspended in $1.2 \mathrm{ml}$ of $4 \%$ low-viscosity alginate ( $6 \%$ stock diluted with binding buffer) and mixed vigorously. The mixture was extruded dropwise into a $0.15 \mathrm{M} \mathrm{CaCl}_{2}$ bath ( $\mathrm{pH}$ 5) using a $21 \mathrm{G}$ needle, and the beads were left to stir at room temperature for $1 \mathrm{~h}$, then rinsed once with binding buffer. The beads were subsequently added to $0.5 \%$ chitosan and left to stir for $10 \mathrm{~min}$, then washed twice with binding buffer and kept at $4^{\circ} \mathrm{C}$ till use. Empty beads and beads containing $1 \mu \mathrm{M}$ SOD (without cells) were prepared as controls.

\section{In vitro Digestion}

Simulated gastric fluid (SGF) was modified from Minekus et al. (2014) and prepared as a $1 \times$ concentrate. This consisted of: $6.9 \mathrm{mM} \mathrm{KCl}, 0.9 \mathrm{mM} \mathrm{KH}_{2} \mathrm{PO}_{4}, 25 \mathrm{mM} \mathrm{NaHCO}_{3}, 47.2 \mathrm{mM} \mathrm{NaCl}$, $0.1 \mathrm{mM} \mathrm{MgCl}_{2}\left(\mathrm{H}_{2} \mathrm{O}\right)_{6}$, and $0.5 \mathrm{mM}\left(\mathrm{NH}_{4}\right)_{2} \mathrm{CO}_{3}$. Pepsin (SigmaAldrich P6887) and all necessary chemicals were purchased from Sigma-Aldrich. Sodium citrate was dissolved in PBS ( $\mathrm{pH} \mathrm{5)}$ at a concentration of $0.15 \mathrm{M}$. Ten alginate-chitosan beads were used for each condition tested. Beads were suspended in 125 $\mu \mathrm{l}$ distilled water and equivolume SGF, with addition of $\mathrm{CaCl}_{2}$ (final concentration $0.075 \mathrm{mM}$ ) and pepsin (final concentration $0.5 \mathrm{mg} / \mathrm{ml}$ ). The mixture was incubated with shaking at $37^{\circ} \mathrm{C}$ for $2 \mathrm{hr}$, then rinsed twice with PBS ( $\mathrm{pH} 7)$. Beads were incubated with $\mathrm{pH} 5 \mathrm{PBS}$ as a control. The beads were dispersed in 250 $\mu \mathrm{l}$ citrate buffer held at $40^{\circ} \mathrm{C}$, then centrifuged at $10,000 \mathrm{~g}$ for $10 \mathrm{~min}$. The cell pellet was resuspended in $250 \mu \mathrm{l} 1 \times \mathrm{PBS}$ ( $\mathrm{pH}$ 5) for the SOD assay. Residual activity represents enzyme activity of SGF-treated beads relative to the control (beads in PBS).

\section{Statistical Analyses}

Statistical analyses were performed using GraphPad Prism v8.0.1 for Windows. Two-tailed Student's $t$-tests were performed to determine the significance of differences in the binding studies. For curve fitting to the Langmuir model, non-linear regression analysis was performed assuming single-site saturation binding. $B_{\max }$ from the analysis was taken as the saturation RFU. 


\section{RESULTS}

\section{Isolation of a Putative Cell Anchoring Domain (CAD4a) From L. plantarum}

A search of the Pfam database revealed 83 homologs of the bacterial SH3 type 5 motif (SH3_5, Pfam PF08460) across the Lactobacillus and Lactococcus genera and their phages. This study focused on a previously uncharacterized SH3_5 anchoring domain in Lys2 (GenBank CCC80137), a muramidase from L. plantarum WCFS1. The full-length muramidase is an $860-$ amino acid protein with an expected molecular weight of 84 $\mathrm{kDa}$, with five SH3_5 repeats (R1-5) at its C-terminus spanning residues 471 and 860 (Figure 1). Each repeat in Lys2 contains 61 residues, and the similarity between the five repeats vary from $50 \%$ to over $90 \%$. The SH3 5 anchoring domain of Lys 2 has $54 \%$ identity to that of Acm2 (GenBank CCC79778), another $L$. plantarum autolysin with similar molecular organization (Rolain et al., 2012). Comparing the first SH3_5 repeat of Lys2 to SH3_5 motifs in the proteins of Streptococcus (GenBank EQC72385, four SH3_5 repeats), Staphylococcus (GenBank AAB53783, single SH3_5), L. lactis phage 1358 (NCBI YP_009140409, single SH3_5), Lactobacillus phage ATCC 8014-B2 (NCBI YP_009783998, single SH3_5), and Staphylococcus phage K (GenBank AHB79986) showed identities of 40, 22, 27, 31, and $21 \%$, respectively, thus the lactobacillal domain is homologous to but quite distinct from other SH3_5 domains in the group of Firmicutes (Supplementary Figure 1).

To assess the surface display potential of this five-repeat SH3_5 domain, we used the Sirius blue fluorescent protein as a reporter (Tomosugi et al., 2009). Sirius was chosen for its photostability at low $\mathrm{pH}(\mathrm{pKa}<3)$. The five-repeat domain was cloned downstream of Sirius in the pET22b plasmid, but the fusion protein was insoluble and difficult to purify (data not shown). A truncated domain containing only R1-R3 (henceforth called CAD4a) gave more tractable expression, and the Sirius conjugate (Si-CAD4a) was easily detected by SDS-PAGE and Western blot against the N-terminal His-tag (Figure 2B). There was some protein degradation during expression, but the bulk of the soluble fraction was the full-length protein.

\section{CAD4a Anchoring to LAB}

Heterologous binding of Si-CAD4a12 (with a 12-residue spacer between Sirius and CAD4a) to LAB was tested using L. lactis, $L$. casei, L. fermentum, L. plantarum, and L. rhamnosus (Table 1). Bacteria in log-phase growth were incubated with $2 \mu \mathrm{M}$ protein without shaking for $2 \mathrm{~h}$ at $37^{\circ} \mathrm{C}$. As shown in Figure 3A, there was $>2$-fold increase in cell-associated fluorescence on $L$. fermentum after exposure to Si-CAD4a12, compared to Sirius without the anchoring domain. Fluorescence microscopy showed that the protein was displayed uniformly across the cell surface (Figure 3D). Negligible binding was seen with L. lactis, L. casei, L. plantarum, and L. rhamnosus, suggesting that the interaction between CAD4a and L. fermentum was selective. There was also more binding to log-phase compared to stationary-phase $L$. fermentum (Figure 3B). This could be due to actively dividing cells having more exposed cell wall structure and fewer surface proteins inhibiting access to the cell wall. Except where otherwise stated, all subsequent binding experiments were carried out with log-phase bacteria.

\section{Cell Wall Target of CAD4a}

The SH3_5 domain is known to bind cross-linked peptidoglycan (PGN) (Desvaux et al., 2018). To confirm that CAD4a binds PGN, L. fermentum was pre-treated with either $5 \mathrm{M} \mathrm{LiCl}$ or $10 \% \mathrm{v} / \mathrm{v}$ TCA before exposure to Si-CAD4a12. TCA hydrolyzes teichoic acids (TAs), one of the major cell wall components, whereas $5 \mathrm{M} \mathrm{LiCl}$ removes non-covalently bound surface proteins. As shown in Figure 3C, treatment with $\mathrm{LiCl}$ led to a

A

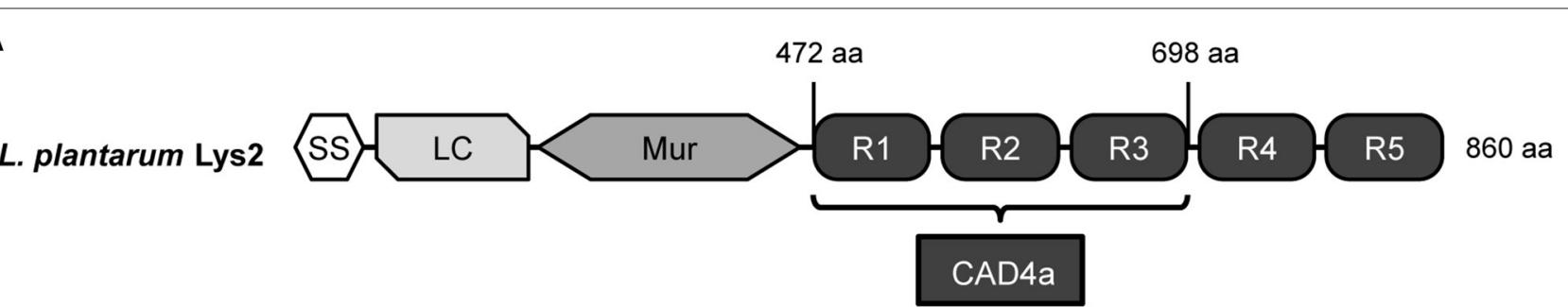

B

1 SGWYTFTKNT AIKSAASDSA KTVGTYSKGN RVYYNAEITT NGETWLRYLS YSGSEHFVKI

61 AAAKTTTTKP AASTSKTVTK NETGTYKFTK TTAIKGSVSD SAKTLGTYYK GDTVYYNAKV

121 TKNGETWLRY LSYSGAQHYV KISGAATSTT TTKPATSSSK TVTKAETGTY KFTGTTAIKG

181 SVNDSAKTLG TYYKGDTVYY NAKVTKNGQT WLRYLSYSGA QHYVKISGAA TTTTTSSKST

241 ATASAKTVAQ SGTYKFAKTT AIKSSASDAA STVGTYYKGN TVNYNAKVTT NGQTWLRYTS

301 YSGAQHYVKV SGGAATTTSS SASKTTAAAG TYTFKTTTNI RTAASLNASV VGQYSAGESV

361 YYIGTVSADG YQWLKYLSNS GAYHYVAKIG

FIGURE 1 | (A) Molecular organization of L. plantarum Lys2 with the C-terminal anchoring region. SS, signal sequence; LC, low complexity region; Mur, muramidase; R1-R5, SH3_5 repeats. (B) Amino acid sequence of the Lys2 anchoring region. Individual SH3_5 repeats are in bold, and the CAD4a domain has been underlined. 
A

\begin{tabular}{|c|c|c|}
\hline Sirius & Sirius & \\
\hline Si-CAD4a12 & Sirius & CAD4a \\
\hline Si-CAD4a24 & Sirius & CAD4a \\
\hline Si-CAD4a36 & Sirius & CAD4a \\
\hline SOD & SOD & \\
\hline SOD-CAD4a12 & SOD & CAD4a \\
\hline SOD-CAD4a24 & $6 \mathrm{H}=\mathrm{SOD}$ & CAD4a \\
\hline SOD-CAD4a36 & $6 \mathrm{H}$ SOD & CAD4a \\
\hline
\end{tabular}

B

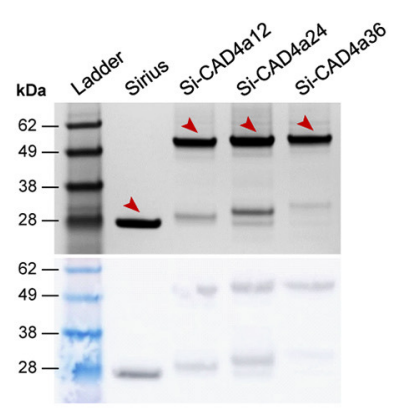

C

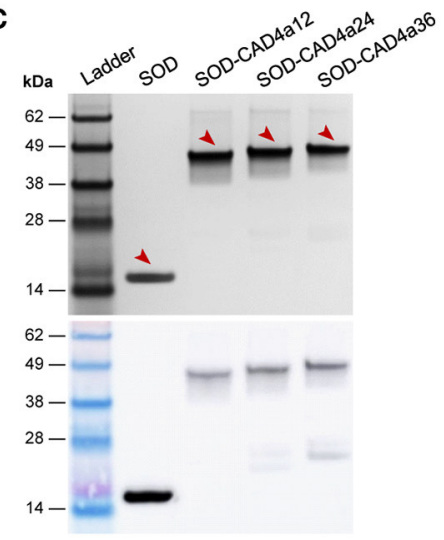

FIGURE 2 | (A) Fusion protein constructs for surface display. 6H, His-tag; CAD4a, SH3_5 anchoring domain containing repeats R1-R3 (25 kDa); Si, Sirius blue fluorescent protein $(28 \mathrm{kDa})$; SOD, superoxide dismutase from Potentilla atrosanguinea (17 kDa). Coomassie blue-stained SDS-PAGE gel (top) and western blot (bottom) of (B) Sirius and Si-CAD4a conjugates, and (C) SOD and SOD-CAD4a conjugates, all purified from E. coli cultures. Blots were labeled with anti-His antibody conjugated to HRP. Arrows indicate expected band position of the full-length proteins.

2-fold increase in cell anchoring, likely because the removal of surface proteins exposed more binding sites within the cell wall. TCA treatment did not significantly impact CAD4a binding, thus the anchoring domain was not targeting cell wall TAs. Taken together, these results suggest that CAD4a is binding to PGN, the other major component of the Gram-positive cell wall. Further, since TCA treatment significantly reduced cell viability (results not shown) but not CAD4a anchoring, changes to cell viability are not likely to impact CAD4a-mediated protein display, so long as the PGN matrix remains intact.

\section{Factors Influencing Binding of CAD4a to $L$. fermentum}

We investigated several binding conditions to see if we could improve surface display on L. fermentum. Ambient temperature had an effect on the rate of binding, with noticeably slower binding at $25^{\circ} \mathrm{C}$ compared to $37^{\circ} \mathrm{C}$ (Figure $4 \mathrm{~A}$ ). At 30 and $37^{\circ} \mathrm{C}$, maximum binding was achieved within $1.5 \mathrm{~h}$. Ionic strength had a negligible effect on binding at low and physiological salt concentrations $(\leq 150 \mathrm{mM} \mathrm{NaCl}$ ), but high salt concentrations ( $>200 \mathrm{mM} \mathrm{NaCl}$ ) adversely affected anchoring, possibly by disrupting the non-covalent interactions between CAD4a and PGN (Figure 4B). We found that $\mathrm{pH} 5$ was optimal for CAD4a anchoring; there was no binding above $\mathrm{pH} 6$, whereas below
$\mathrm{pH}$ 5, non-specific binding of Sirius became significant and the contribution of CAD4a was less clear (Figure 4C).

To determine the binding capacity of CAD4a on stationaryphase L. fermentum, different concentrations of Si-CAD4a were mixed with overnight cultures diluted to $\mathrm{OD}_{600}=1.5\left(\sim 10^{9}\right.$ cells $/ \mathrm{ml}$ ). As shown in Figure 5A, cell-associated fluorescence increased in a dose-dependent manner before reaching a plateau, with $B_{\max }$ determined to be $\sim 378 \mathrm{RFU}$ after fitting to a Langmuir adsorption isotherm $\left(r^{2}=0.766\right)$. This corresponded to a saturation concentration of $1.05 \mu \mathrm{M}$ protein (Figure 5B), or an average of $5 \times 10^{5}$ molecules per cell.

\section{Heterologous Display of Superoxide Dismutase via CAD4a}

To demonstrate the surface display of a functional protein using CAD4a, we cloned and expressed a superoxide dismutase (SOD) from $P$. atrosanguinea with CAD4a at its C-terminus. SOD is an enzyme that scavenges reactive oxygen radicals and has potential application in treating intestinal inflammation, based on positive outcomes in mouse models (Seguí et al., 2004). We constructed three SOD-CAD4a variants with 12-, 24-, and 36-residue glycine-serine (GS) spacers (Figure 2A) to examine if spacer length affects protein activity after anchoring. Active SOD is a homodimeric complex, and a short linker could 
A

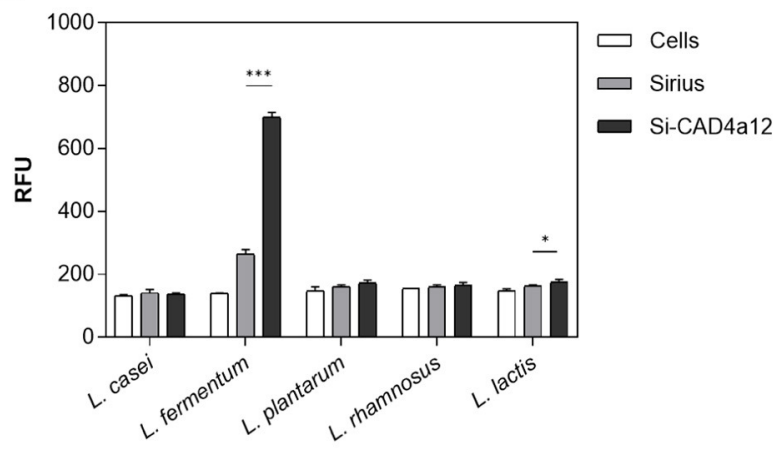

B
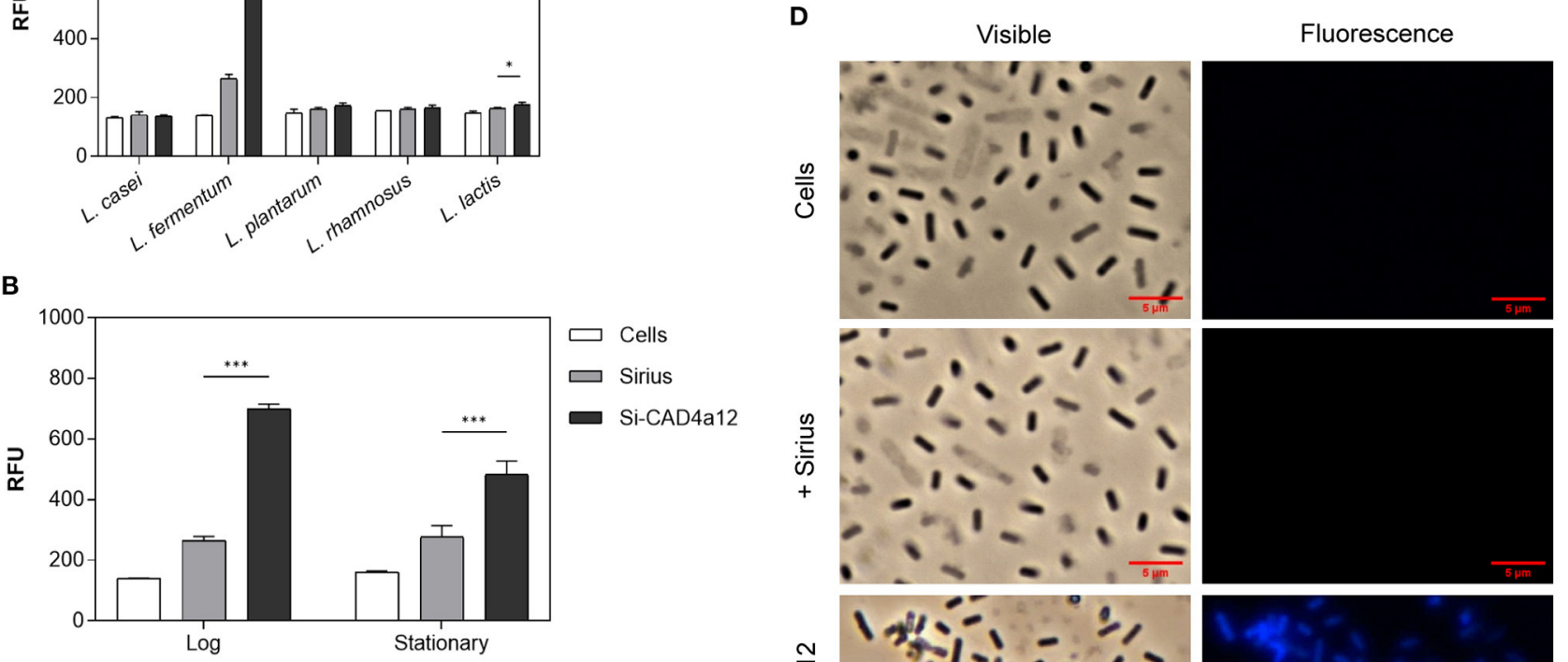

C
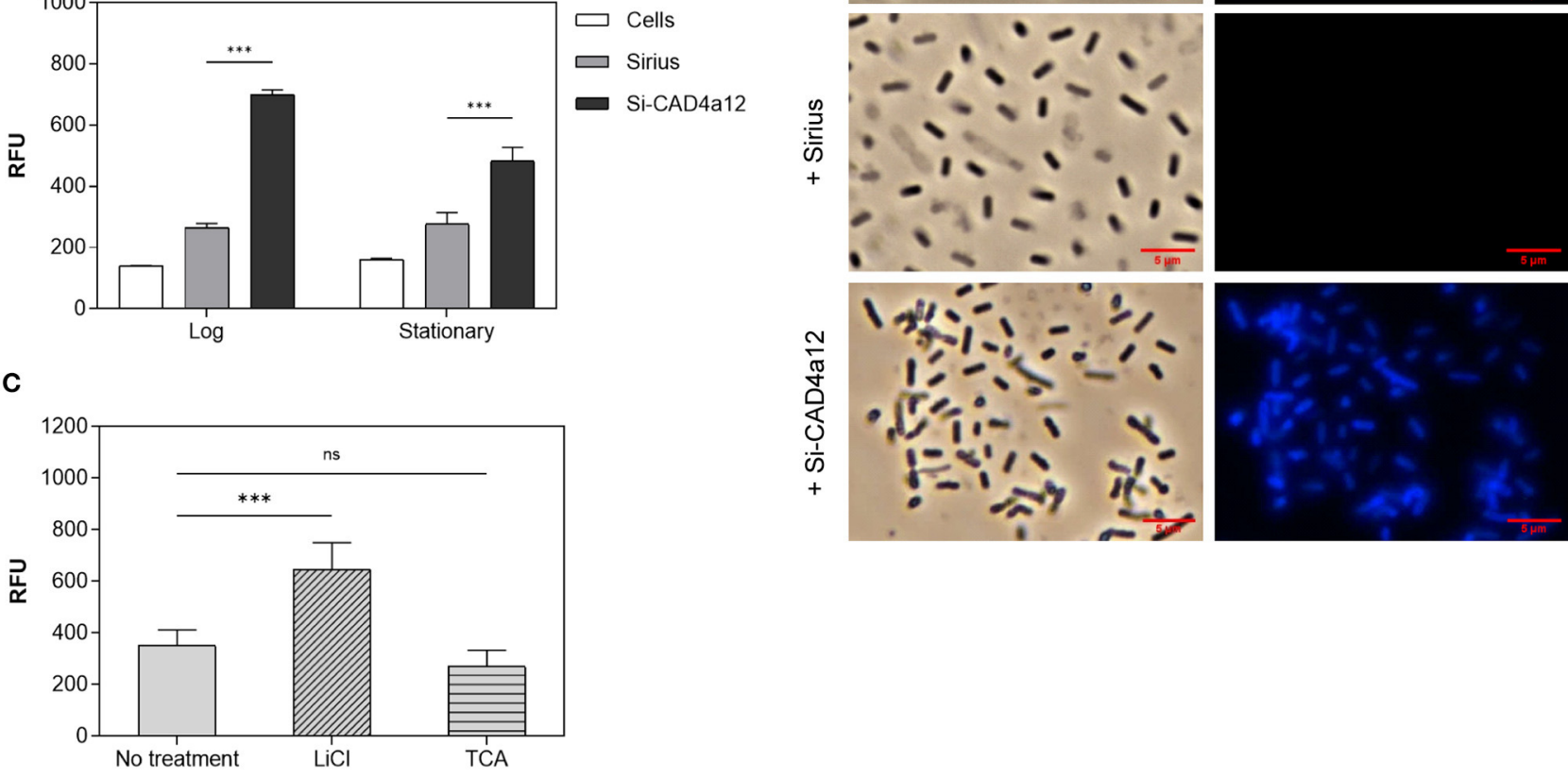

FIGURE 3 | CAD4a12 anchors selectively to L. fermentum. Cell-associated fluorescence after Si-CAD4a12 was exposed to (A) L. casei, L. fermentum, L. plantarum, L. rhamnosus, and L. lactis in log-phase growth; and (B) L. fermentum in log- and stationary-phase growth. (C) Effect of pre-treatment of $L$. fermentum with $5 \mathrm{M} L \mathrm{LiCl}$ or 10\% v/v TCA on CAD-4a12 anchoring. (D) Fluorescence micrographs of log-phase L. fermentum (top), and cells exposed to Sirius (middle) and Si-CAD4a12 (bottom). Phase contrast image on left and fluorescence image on right (DAPI filter). $n=3 . n s, p>0.05 ;{ }^{\star} p \leq 0.05 ;{ }^{* \star \star} p \leq 0.001$ vs. control.

have impacted its dimerization and thus enzyme activity. Fulllength protein was obtained for all three variants following expression and purification from E. coli cultures (Figure 2C). A comparison of enzyme activity showed that SOD-CAD4a12 had slightly reduced activity compared to SOD and the other spacer variants, although the difference was not statistically significant (Supplementary Figure 2A). We did not observe the same effect of spacer length on the monomeric Sirius, as fluorescence output of Sirius conjugates with different spacer lengths did not differ significantly (Supplementary Figure 2B).

The SOD variants were used for subsequent binding experiments. As shown in Figure 6, there was more non-specific binding for SOD compared to Sirius, but the addition of the anchoring domain increased cell-associated enzyme activity by $\sim 40 \%$. All three spacer variants gave very similar activity after cell anchoring (Figure 6), thus spacer length had minimal effect on the functionality of the anchored domain. The native spacer in the L. plantarum muramidase is 33 amino acids long. Our results suggest that shorter spacers could be used, although the ideal length is protein-dependent, and should be optimized based on size and multimericity of the target protein.

\section{Gastric Resistance of Encapsulated SOD-Coated Bacteria}

We found that anchored Si-CAD4a was sufficiently surfaceexposed to be digested when cells underwent simulated gastric digestion (Supplementary Figure 3). There was thus a need to protect surface-displayed protein from detachment and/or degradation under changing and potentially adverse ambient conditions. Nualkaekul et al. showed that a matrix of alginate 

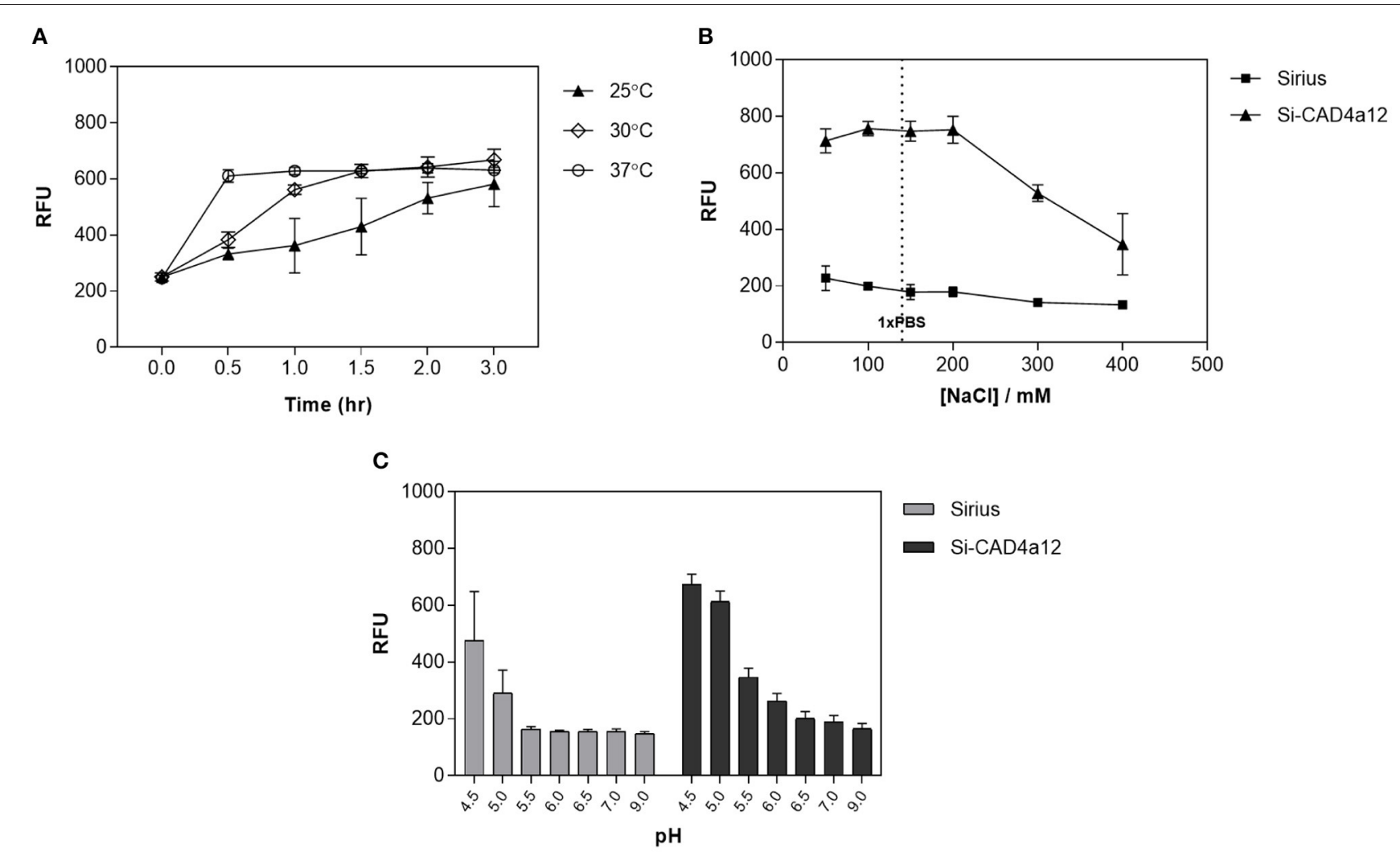

FIGURE 4 | Anchoring of Si-CAD4a12 under different conditions. (A) Time-course of anchoring at different temperatures. Anchoring at (B) different $\mathrm{NaCl}$ concentrations, and (C) different pH. $n=3$.
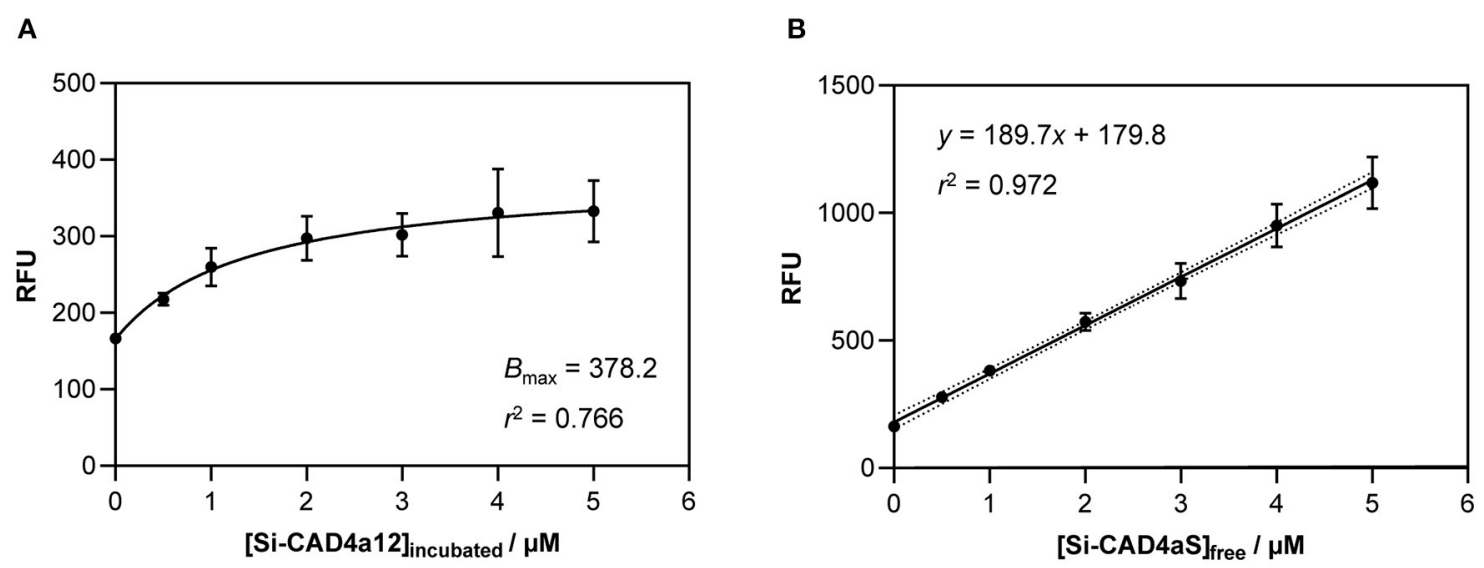

FIGURE 5 | Binding curve for anchoring of Si-CAD4a12 to overnight cultures of $L$. fermentum. Data points represent the average and standard deviation of at least three independent experiments. Points were fitted to a Langmuir adsorption isotherm to determine fluorescence at saturation (A), and concentration at saturation was calculated from a standard curve (B).

coated in chitosan helped to buffer $\mathrm{pH}$ changes and maintained the viability of $L$. plantarum in acidic media (Nualkaekul et al., 2012). To maintain optimal conditions for CAD4a anchoring during encapsulation, SOD-coated cells mixed with alginate were gelled in a $\mathrm{Ca}^{2+}$ bath at $\mathrm{pH} 5$, and the alginate beads were then coated with a chitosan solution, also at pH 5. Gastric resistance was evaluated using simulated gastric fluid (SGF) at $\mathrm{pH}$ 3 containing the gastric protease pepsin (Minekus et al., 2014). Following gastric digestion, beads were treated with a citrate solution at $\mathrm{pH} 5$ to chelate the $\mathrm{Ca}^{2+}$ ions and disperse the matrix. Subsequent activity assays on the pelleted cells showed that over $90 \%$ of cell-associated enzyme activity was retained (Figure 7A), 
thus the polymer matrix offered substantial protection for the surface-displayed enzyme. In comparison, there was less residual enzyme activity (72\%) in beads that contained unanchored SOD (Figure 7A), suggesting that cell anchoring also confers some protection to the protein, perhaps by limiting protein diffusion within the matrix. A Western blot of the cell pellet showed that the anchoring domain was intact, thus the enzyme likely remained anchored to the cell surface (Figure 7B).

\section{DISCUSSION}

The first SH3_5 anchoring motif was identified in staphylococcal endolysins and helped to localize the latter to its cell wall targets

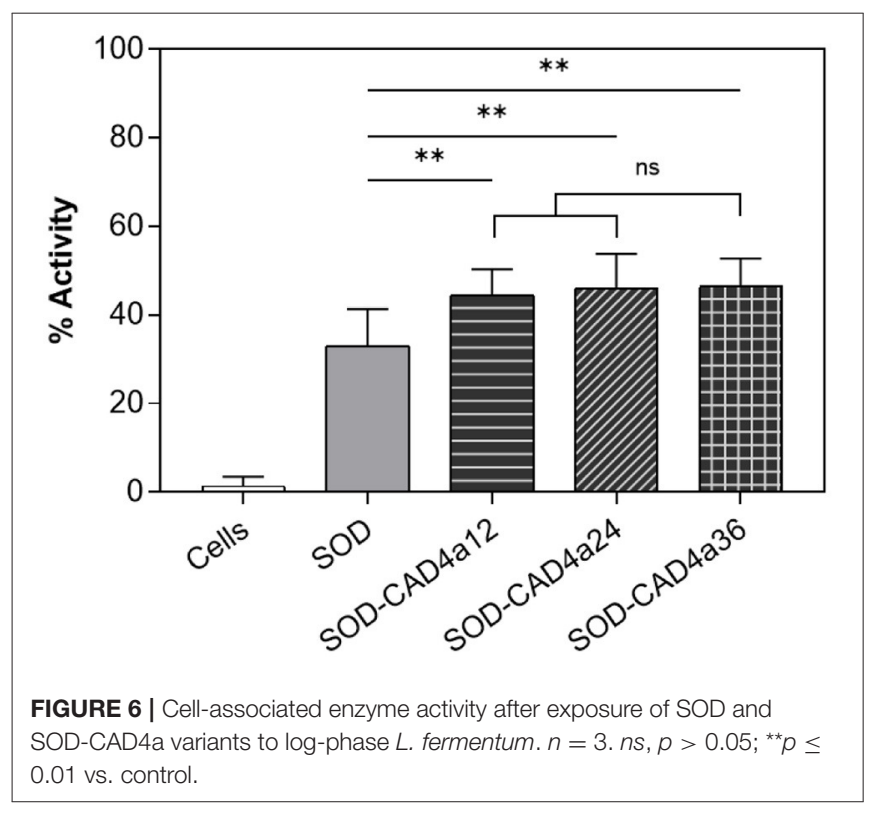

(Baba and Schneewind, 1996; Gründling and Schneewind, 2006). These domains, along with similar ones from phages, contained a single SH3_5 motif. In contrast, SH3_5-based anchoring domains from Streptococcus and Lactobacillus can have multiple SH3_5 repeats, up to six in tandem for some species. Such domains from Lactobacillus have not been investigated for protein surface display, where the multiplicity of SH3_5 may provide stronger cell wall binding. This work examined the anchoring domain of the L. plantarum Lys2 autolysin, which contains five terminal SH3_5 repeats. From the Lys2 cell wall targeting region, a truncated three-repeat domain, which we named CAD4a, was successfully expressed as part of fusion proteins. We tested five strains of LAB for anchoring of CAD4a, and found selective binding to L. fermentum. It was surprising that CAD4a bound poorly to the $L$. plantarum strain that we tested (ATCC 8014), since it was derived from another $L$. plantarum strain (WCFS1). However, the surface of L. plantarum is known to be covered in capsular polysaccharides, which were shown to inhibit Acm 2 binding in a previous study (Beaussart et al., 2013), and could have had a similar shielding effect toward CAD4a anchoring. Although the surface composition of L. fermentum is not well-characterized, it is likely that a lack of significant polysaccharide coverage made this bacterium a more ideal host for CAD4a binding. Alternatively, all five of the SH3_5 repeats might be essential for proper binding to the L. plantarum cell wall, similar to the LysM domain in lactococcal AcmA, which requires all three of its LysM repeats for optimal PGN binding (Steen et al., 2005).

We have shown that CAD4a binds to cell wall peptidoglycan (PGN), though its ligand is uncertain. Existing molecular models for PGN-SH3_5 interactions were based on staphylococcal domains, where it was shown that SH3_5 recognized pentapeptide cross-bridges in PGN (Mitkowski et al., 2019; Gonzalez-Delgado et al., 2020). However, such cross-bridges are absent in lactobacilli (Kleerebezem et al., 2010), and the section in staphylococcal SH3_5 that binds the cross-bridges
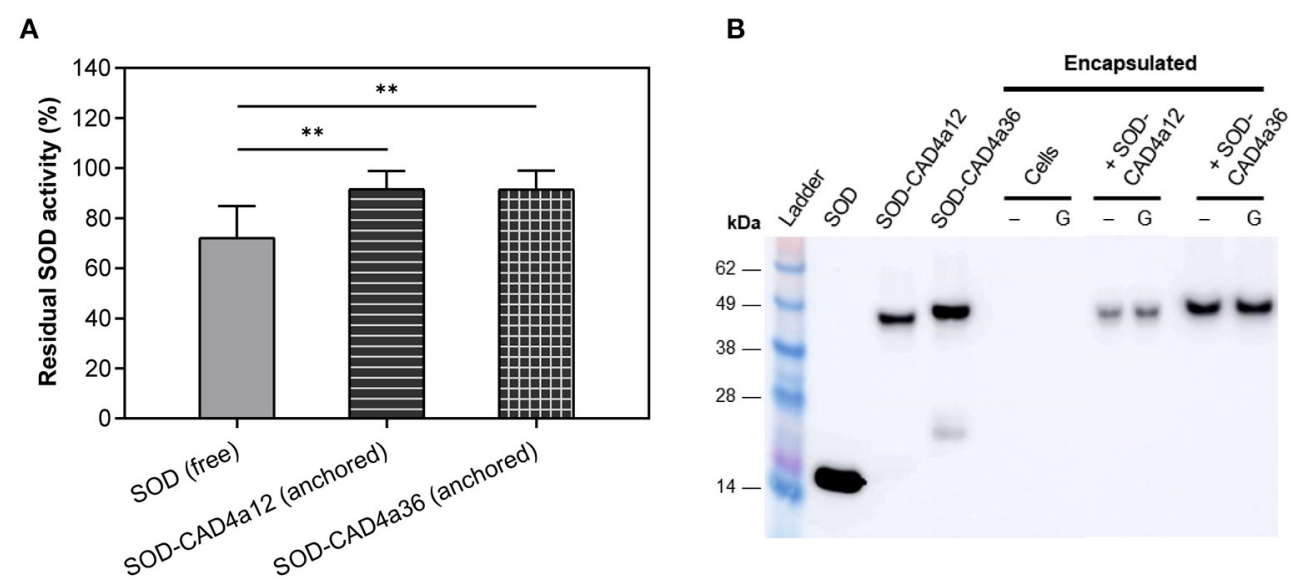

FIGURE 7 | Outcome of in vitro gastric digestion of free SOD and SOD-coated L. fermentum, both in chitosan-alginate beads. Beads were digested with pH 3 SGF containing pepsin, then dispersed and the cells pelleted down for the SOD activity assay. (A) Residual enzyme activity, calculated as cell-associated activity after digestion relative to undigested control beads left in pH 5 PBS. (B) Western blot of resuspended cell pellets that were untreated (-) or underwent gastric digestion (G). Proteins were labeled with anti-His antibody. The first three lanes after the protein ladder are pure proteins for reference. ${ }^{* \star} p \leq 0.01$ vs. control. 
is notably absent from CAD4a. Instead, CAD4a may anchor similar to LysM, another PGN-binding motif commonly used for surface display. LysM recognizes a generic GlcNAc-X-GlcNAc motif in PGN glycans, but its binding affinity is modulated by neighboring peptide stems, thus providing some measure of selectivity (Mesnage et al., 2014). It was recently shown that the SH3_5 domain of L. plantarum Acm2 autolysin also has an affinity for PGN glycan chains containing GlcNAc, although the authors did not examine the influence of PGN peptide stems (Beaussart et al., 2013). It is thus possible that the SH3_5 and LysM binding motifs recognize similar PGN ligands, and cannot be used concurrently for protein display.

Stationary-phase bacteria bound less protein than log-growth bacteria, but are more robust to handling and gastrointestinal transit, and are thus of greater practical importance, especially for in vivo delivery applications that require viable cells (Brashears and Gilliland, 1995; Lorca and De Valdez, 1999; Corcoran et al., 2004; Broeckx et al., 2020). Stationary-phase L. fermentum bound $10^{5}$ molecules of monomeric protein per cell. This compares well with previously reported binding capacities for LysM and S-layer-derived anchoring domains, which ranged from $10^{3}$ to $10^{6}$ molecules/cell (Bosma et al., 2006; Hu et al., 2010, 2011; Ravnikar et al., 2010). The binding capacity is likely to vary with the size and multimericity of the protein. Improvement in binding was reported for other anchoring domains after pretreating bacteria with various solvents and detergents ( $\mathrm{Hu}$ et al., 2010, 2011; Xu et al., 2011); we have also shown that $5 \mathrm{M} \mathrm{LiCl}$ treatment improves binding of CAD4a (Figure 3C). However, such treatments disrupt the proteosurfaceome of bacteria, and could have knock-on effects on cell viability and host-microbe interactions in vivo, and so should be used judiciously.

The optimal $\mathrm{pH}$ for CAD4a anchoring ( $\mathrm{pH}$ 5) means that coated bacteria must be kept under slightly acidic conditions to maintain surface display. This precludes the display of acid-sensitive proteins - an important limitation of the CAD4a anchoring domain-although many lactobacilli can still thrive under these conditions, and L. fermentum is known to tolerate $\mathrm{pH}$ values down to 4.5 (Calderon Santoyo et al., 2003; LeBlanc et al., 2004). Encapsulation in a polymer matrix can further protect the anchored protein from the harsh conditions of gastrointestinal transit. We have shown that one such matrix, a composite of the natural polymers alginate and chitosan which can be assembled under acidic conditions, can protect surfaceanchored protein from gastric digestion; other enteric coatings are reviewed elsewhere (Ramos et al., 2018; Gomand et al., 2019).

We have shown that CAD4a could be used to display SOD on the surface of L. fermentum, with minimal effect on enzyme functionality. Various strains of L. fermentum are known to have probiotic effects (Geier et al., 2007; Peran et al., 2007; Mikelsaar and Zilmer, 2009; Garcia-Castillo et al., 2019); whether these could enhance the therapeutic outcome of displayed functionalities could form the basis of future studies. It was shown previously that recombinant lactobacilli engineered to secrete SOD can ameliorate intestinal inflammation in mouse models of inflammatory bowel disease (Carroll et al., 2007; Watterlot et al., 2010; Hou et al., 2014). The SOD produced complemented inherent antioxidative and immunomodulatory properties of the probiotic Lactobacillus strains. However, such genetically modified bacteria might face stringent regulatory scrutiny and poor public acceptance. Heterologous display of therapeutic domains like SOD using CAD4a on wild-type LAB could get around these constraints, since no recombinant DNA is introduced to lactobacilli, and these bacteria could potentially be sourced from healthy microbiomes. We are currently looking into protein surface display using CAD4a for treatment of intestinal disease and for mucosal vaccination.

To conclude, we have characterized the use of CAD4a, a novel SH3_5-based anchoring domain, for surface display of heterologous proteins on LAB. C-terminal conjugation of the domain enabled the anchoring and display of two different proteins on L. fermentum, with optimal anchoring at $\mathrm{pH} 5$, and up to $10^{5}$ monomeric protein displayed per cell. Besides the delivery of therapeutic proteins to the gut, we foresee that surface display mediated by CAD4a could be also be used in the development of mucosal vaccines and for industrial biocatalysis.

\section{DATA AVAILABILITY STATEMENT}

The original contributions presented in the study are included in the article/Supplementary Material, further inquiries can be directed to the corresponding author/s.

\section{AUTHOR CONTRIBUTIONS}

PT and DO conceptualized the study and interpreted the results. PT designed and performed the experiments. PL helped with cloning and performed experiments involving SOD. PT drafted the manuscript and DO edited it. All authors reviewed the final manuscript.

\section{FUNDING}

This research was supported by the Agency for Science, Technology and Research (A*STAR), Singapore, under its Industry Alignment Fund (Pre-Positioning) Food Structure Engineering for Nutrition and Health (FSENH) programme (H18/01/a0/C11).

\section{ACKNOWLEDGMENTS}

The authors thank Lesaffre APAC for contributing a sample of Lactobacillus rhamnosus GG.

\section{SUPPLEMENTARY MATERIAL}

The Supplementary Material for this article can be found online at: https://www.frontiersin.org/articles/10.3389/fbioe. 2020.614498/full\#supplementary-material 


\section{REFERENCES}

Åvall-Jääskeläinen, S., Kylä-Nikkilä, K., Kahala, M., Miikkulainen-Lahti, T., and Palva, A. (2002). Surface display of foreign epitopes on the Lactobacillus brevis S-Layer. Appl. Environ. Microbiol. 68:5943. doi: 10.1128/AEM.68.12.5943-5951.2002

Baba, T., and Schneewind, O. (1996). Target cell specificity of a bacteriocin molecule: a C-terminal signal directs lysostaphin to the cell wall of Staphylococcus aureus. ЕMBO J. 15, 4789-4797. doi: 10.1002/j.1460-2075.1996.tb00859.x

Beaussart, A., Rolain, T., Duchene, M. C., El-Kirat-Chatel, S., Andre, G., Hols, P., et al. (2013). Binding mechanism of the peptidoglycan hydrolase Acm2: low affinity, broad specificity. Biophys. J. 105, 620-629. doi: 10.1016/j.bpj.2013.06.035

Becker, S. C., Foster-Frey, J., Stodola, A. J., Anacker, D., and Donovan, D. M. (2009). Differentially conserved staphylococcal SH3b_5 cell wall binding domains confer increased staphylolytic and streptolytic activity to a streptococcal prophage endolysin domain. Gene 443, 32-41. doi: 10.1016/j.gene.2009.04.023

Bosma, T., Kanninga, R., Neef, J., Audouy, S. A., Van Roosmalen, M. L., Steen, A., et al. (2006). Novel surface display system for proteins on nongenetically modified gram-positive bacteria. Appl. Environ. Microbiol. 72, 880-889. doi: 10.1128/AEM.72.1.880-889.2006

Brashears, M. M., and Gilliland, S. E. (1995). Survival during frozen and subsequent refrigerated storage of Lactobacillus acidophilus cells as influenced by the growth phase. J. Dairy Sci. 78, 2326-2335. doi: 10.3168/jds.S0022-0302(95)76859-X

Brinster, S., Furlan, S., and Serror, P. (2007). C-terminal WxL domain mediates cell wall binding in Enterococcus faecalis and other gram-positive bacteria. J. Bacteriol. 189, 1244-1253. doi: 10.1128/JB.00773-06

Broeckx, G., Kiekens, S., Jokicevic, K., Byl, E., Henkens, T., Vandenheuvel, D., et al. (2020). Effects of initial cell concentration, growth phase, and process parameters on the viability of Lactobacillus rhamnosus GG after spray drying. Drying Technol. 38, 1474-1492. doi: 10.1080/07373937.2019.1648290

Calderon Santoyo, M., Loiseau, G., Rodriguez Sanoja, R., and Guyot, J.-P. (2003). Study of starch fermentation at low $\mathrm{pH}$ by Lactobacillus fermentum ogi E1 reveals uncoupling between growth and a-amylase production at $\mathrm{pH}$ 4.0. Int. J. Food Microbiol. 80, 77-87. doi: 10.1016/S0168-1605(02)00140-X

Cano-Garrido, O., Seras-Franzoso, J., and Garcia-Fruitós, E. (2015). Lactic acid bacteria: reviewing the potential of a promising delivery live vector for biomedical purposes. Microb. Cell Fact. 14, 137-137. doi: 10.1186/s12934-015-0313-6

Carroll, I. M., Andrus, J. M., Bruno-Barcena, J. M., Klaenhammer, T. R., Hassan, H. M., and Threadgill, D. S. (2007). Anti-inflammatory properties of Lactobacillus gasseri expressing manganese superoxide dismutase using the interleukin 10deficient mouse model of colitis. Am. J. Physiol. Gastrointest. Liver Physiol. 293, G729-738. doi: 10.1152/ajpgi.00132.2007

Chowdhury, M. Y., Li, R., Kim, J. H., Park, M. E., Kim, T. H., Pathinayake, P., et al. (2014). Mucosal vaccination with recombinant Lactobacillus casei-displayed CTA1-conjugated consensus matrix protein-2 (sM2) induces broad protection against divergent influenza subtypes in BALB/c mice. PLoS ONE 9:e94051. doi: 10.1371/journal.pone.0094051

Corcoran, B. M., Ross, R. P., Fitzgerald, G. F., and Stanton, C. (2004). Comparative survival of probiotic lactobacilli spray-dried in the presence of prebiotic substances. J. Appl. Microbiol. 96, 1024-1039. doi: $10.1111 / j .1365-2672.2004 .02219 . x$

Desvaux, M., Candela, T., and Serror, P. (2018). Surfaceome and proteosurfaceome in parietal monoderm bacteria: focus on protein cell-surface display. Front. Microbiol. 9:100. doi: 10.3389/fmicb.2018.00100

Dieye, Y., Usai, S., Clier, F., Gruss, A., and Piard, J. C. (2001). Design of a protein-targeting system for lactic acid bacteria. J. Bacteriol. 183:4157. doi: 10.1128/JB.183.14.4157-4166.2001

Fleetwood, F., Devoogdt, N., Pellis, M., Wernery, U., Muyldermans, S., Ståhl, S., et al. (2013). Surface display of a single-domain antibody library on Gram-positive bacteria. Cell. Mol. Life Sci. 70, 1081-1093. doi: 10.1007/s00018-012-1179-y

Fredriksen, L., Kleiveland, C. R., Olsen Hult, L. T., Lea, T., Nygaard, C. S., Eijsink, V. G. H., et al. (2012). Surface display of N-terminally anchored invasin by Lactobacillus plantarum activates NF- $\mathrm{B}$ in monocytes. Appl. Environ. Microbiol. 78, 5864-5871. doi: 10.1128/AEM.01227-12

Fredriksen, L., Mathiesen, G., Sioud, M., and Eijsink, V. G. H. (2010). Cell wall anchoring of the 37-kilodalton oncofetal antigen by Lactobacillus plantarum for mucosal cancer vaccine delivery. Appl. Environ. Microbiol. 76:7359. doi: 10.1128/AEM.01031-10

Garcia-Castillo, V., Komatsu, R., Clua, P., Indo, Y., Takagi, M., Salva, S., et al. (2019). Evaluation of the immunomodulatory activities of the probiotic strain Lactobacillus fermentum UCO-979C. Front. Immunol. 10:1376. doi: 10.3389/fimmu.2019.01376

Geier, M. S., Butler, R. N., Giffard, P. M., and Howarth, G. S. (2007). Lactobacillus fermentum BR11, a potential new probiotic, alleviates symptoms of colitis induced by dextran sulfate sodium (DSS) in rats. Int. J. Food Microbiol. 114, 267-274. doi: 10.1016/j.ijfoodmicro.2006.09.018

Gill, H., and Prasad, J. (2008). "Probiotics, immunomodulation, and health benefits," in Bioactive Components of Milk, ed. Z. Bösze (New York, NY: Springer), 423-454. doi: 10.1007/978-0-387-74087-4_17

Gomand, F., Borges, F., Burgain, J., Guerin, J., Revol-Junelles, A. M., and Gaiani, C. (2019). Food matrix design for effective lactic acid bacteria delivery. Ann. Rev. Food Sci. Technol. 10, 285-310. doi: 10.1146/annurev-food-032818-121140

Gonzalez-Delgado, L. S., Walters-Morgan, H., Salamaga, B., Robertson, A. J., Hounslow, A. M., Jagielska, E., et al. (2020). Two-site recognition of Staphylococcus aureus peptidoglycan by lysostaphin SH3b. Nat. Chem. Biol. 16, 24-30. doi: 10.1038/s41589-019-0393-4

Gründling, A., and Schneewind, O. (2006). Cross-linked peptidoglycan mediates lysostaphin binding to the cell wall envelope of Staphylococcus aureus. J. Bacteriol. 188, 2463-2472. doi: 10.1128/JB.188.7.2463-2472.2006

Han, L., Zhao, Y., Cui, S., and Liang, B. (2018). Redesigning of microbial cell surface and its application to whole-cell biocatalysis and biosensors. Appl. Biochem. Biotechnol. 185, 396-418. doi: 10.1007/s12010-017-2662-6

Hernani Mde, L., Ferreira, P. C., Ferreira, D. M., Miyaji, E. N., Ho, P. L., and Oliveira, M. L. (2011). Nasal immunization of mice with Lactobacillus casei expressing the pneumococcal surface protein $\mathrm{C}$ primes the immune system and decreases pneumococcal nasopharyngeal colonization in mice. FEMS Immunol. Med. Microbiol. 62, 263-272. doi: 10.1111/j.1574-695X.2011.00809.x

Hou, C. L., Zhang, J., Liu, X. T., Liu, H., Zeng, X. F., and Qiao, S. Y. (2014). Superoxide dismutase recombinant Lactobacillus fermentum ameliorates intestinal oxidative stress through inhibiting NF-кB activation in a trinitrobenzene sulphonic acid-induced colitis mouse model. J. Appl. Microbiol. 116, 1621-1631. doi: 10.1111/jam.12461

Hu, S., Kong, J., Kong, W., Guo, T., and Ji, M. (2010). Characterization of a novel LysM domain from Lactobacillus fermentum bacteriophage endolysin and its use as an anchor to display heterologous proteins on the surfaces of lactic acid bacteria. Appl. Environ. Microbiol. 76, 2410-2418. doi: 10.1128/AEM.01752-09

Hu, S., Kong, J., Sun, Z., Han, L., Kong, W., and Yang, P. (2011). Heterologous protein display on the cell surface of lactic acid bacteria mediated by the s-layer protein. Microb. Cell Fact. 10:86. doi: 10.1186/1475-2859-10-86

Hudson, E. P., Uhlen, M., and Rockberg, J. (2012). Multiplex epitope mapping using bacterial surface display reveals both linear and conformational epitopes. Sci. Rep. 2:706. doi: 10.1038/srep00706

Hui, C., Guo, Y., Zhang, W., Gao, C., Yang, X., Chen, Y., et al. (2018). Surface display of PbrR on Escherichia coli and evaluation of the bioavailability of lead associated with engineered cells in mice. Sci. Rep. 8:5685. doi: 10.1038/s41598-018-24134-3

Kleerebezem, M., Hols, P., Bernard, E., Rolain, T., Zhou, M., Siezen, R. J., et al. (2010). The extracellular biology of the lactobacilli. FEMS Microbiol. Rev. 34, 199-230. doi: 10.1111/j.1574-6976.2009.00208.x

Kosler, S., Strukelj, B., and Berlec, A. (2017). Lactic acid bacteria with concomitant IL-17, IL-23 and TNF $\alpha$-binding ability for the treatment of Inflammatory Bowel Disease. Curr. Pharm. Biotechnol. 18, 318-326. doi: 10.2174/1389201018666170210152218

Kumar, A., Dutt, S., Bagler, G., Ahuja, P. S., and Kumar, S. (2012). Engineering a thermo-stable superoxide dismutase functional at sub-zero to $>50^{\circ} \mathrm{C}$, which also tolerates autoclaving. Sci. Rep. 2:387. doi: 10.1038/srep00387

LeBlanc, J. G., Garro, M. S., and Savoy De Giori, G. (2004). Effect of pH on Lactobacillus fermentum growth, raffinose removal, alpha-galactosidase activity and fermentation products. Appl. Microbiol. Biotechnol. 65, 119-123. doi: $10.1007 / \mathrm{s} 00253-003-1532-\mathrm{z}$ 
Lee, J. S., Poo, H., Han, D. P., Hong, S. P., Kim, K., Cho, M. W., et al. (2006). Mucosal immunization with surface-displayed severe acute respiratory syndrome coronavirus spike protein on Lactobacillus casei induces neutralizing antibodies in mice. J. Virol. 80, 4079-4087. doi: 10.1128/JVI.80.8.4079-4087.2006

Lei, H., Sheng, Z., Ding, Q., Chen, J., Wei, X., Lam, D. M.-K., et al. (2011). Evaluation of oral immunization with recombinant avian influenza virus HA1 displayed on the Lactococcus lactis surface and combined with the mucosal adjuvant cholera toxin subunit B. Clin. Vacc. Immunol. 18, 1046-1051. doi: 10.1128/CVI.00050-11

Liu, J., Yang, G. L., Gao, X., Zhang, Z., Liu, Y., Yang, X., et al. (2019). Immunomodulatory properties of Lactobacillus plantarum NC8 expressing an anti-CD11c single-chain Fv fragment. J. Microbiol. Biotechnol. 29, 160-170. doi: $10.4014 / \mathrm{jmb} .1809 .09017$

Lorca, G. L., and De Valdez, G. F. (1999). The effect of suboptimal growth temperature and growth phase on resistance of Lactobacillus acidophilus to environmental stress. Cryobiology 39, 144-149. doi: 10.1006/cryo.1999.2193

Mao, R., Wu, D., Hu, S., Zhou, K., Wang, M., and Wang, Y. (2017). Secretory expression and surface display of a new and biologically active single-chain insulin (SCI-59) analog by lactic acid bacteria. Appl. Microbiol. Biotechnol. 101, 3259-3271. doi: 10.1007/s00253-017-8125-8

Mao, R., Zhou, K., Han, Z., and Wang, Y. (2016). Subtilisin QK-2: secretory expression in Lactococcus lactis and surface display onto grampositive enhancer matrix (GEM) particles. Microb. Cell Fact. 15:80. doi: 10.1186/s12934-016-0478-7

Maruthamuthu, M. K., Selvamani, V., Nadarajan, S. P., Yun, H., Oh, Y.-K., Eom, G. T., et al. (2018). Manganese and cobalt recovery by surface display of metal binding peptide on various loops of OmpC in Escherichia coli. J. Indust. Microbiol. Biotechnol. 45, 31-41. doi: 10.1007/s10295-017-1989-x

Mesnage, S., Dellarole, M., Baxter, N. J., Rouget, J.-B., Dimitrov, J. D., Wang, N., et al. (2014). Molecular basis for bacterial peptidoglycan recognition by LysM domains. Nat. Comm. 5:4269. doi: 10.1038/ncomms5269

Mikelsaar, M., and Zilmer, M. (2009). Lactobacillus fermentum ME-3 - an antimicrobial and antioxidative probiotic. Microb. Ecol. Health Dis. 21, 1-27. doi: 10.1080/08910600902815561

Minekus, M., Alminger, M., Alvito, P., Ballance, S., Bohn, T., Bourlieu, C., et al. (2014). A standardised static in vitro digestion method suitable for food - an international consensus. Food Funct. 5, 1113-1124. doi: 10.1039/C3FO60702J

Mitkowski, P., Jagielska, E., Nowak, E., Bujnicki, J. M., Stefaniak, F., Niedzialek, D., et al. (2019). Structural bases of peptidoglycan recognition by lysostaphin SH3b domain. Sci. Rep. 9:5965. doi: 10.1038/s41598-019-42435-z

Mora-Villalobos, J. A., Montero-Zamora, J., Barboza, N., Rojas-Garbanzo, C., Usaga, J., Redondo-Solano, M., et al. (2020). Multi-product lactic acid bacteria fermentations: a review. Fermentation 6:23. doi: 10.3390/fermentation6010023

Mustafa, A. D., Kalyanasundram, J., Sabidi, S., Song, A., a,--L., Abdullah, M., et al. (2018). Proof of concept in utilizing in-trans surface display system of Lactobacillus plantarum as mucosal tuberculosis vaccine via oral administration in mice. BMC Biotechnol. 18:63. doi: 10.1186/s12896-018-0461-y

Narita, J., Okano, K., Kitao, T., Ishida, S., Sewaki, T., Sung, M. H., et al. (2006). Display of alpha-amylase on the surface of Lactobacillus casei cells by use of the PgsA anchor protein, and production of lactic acid from starch. Appl. Environ. Microbiol. 72, 269-275. doi: 10.1128/AEM.72.1.269-275.2006

Nguyen, H.-M., Pham, M.-L., Stelzer, E. M., Plattner, E., Grabherr, R., Mathiesen, G., et al. (2019). Constitutive expression and cell-surface display of a bacterial $\beta$-mannanase in Lactobacillus plantarum. Microb. Cell Fact. 18:76. doi: 10.1186/s12934-019-1124-y

Nualkaekul, S., Lenton, D., Cook, M. T., Khutoryanskiy, V. V., and Charalampopoulos, D. (2012). Chitosan coated alginate beads for the survival of microencapsulated Lactobacillus plantarum in pomegranate juice. Carbohydr. Polym. 90, 1281-1287. doi: 10.1016/j.carbpol.2012.06.073

Park, M. (2020). Surface display technology for biosensor applications: a review. Sensors 20:2775. doi: 10.3390/s20102775

Peran, L., Sierra, S., Comalada, M., Lara-Villoslada, F., Bailón, E., Nieto, A., et al. (2007). A comparative study of the preventative effects exerted by two probiotics, Lactobacillus reuteri and Lactobacillus fermentum, in the trinitrobenzenesulfonic acid model of rat colitis. Brit. J. Nutrition 97, 96-103. doi: $10.1017 /$ S0007114507257770
Pham, M.-L., Tran, A.-M., Kittibunchakul, S., Nguyen, T.-T., Mathiesen, G., and Nguyen, T.-H. (2019). Immobilization of $\beta$-galactosidases on the Lactobacillus cell surface using the peptidoglycan-binding motif LysM. Catalysts 9, 443-443. doi: $10.3390 /$ catal9050443

Plavec, T. V., and Berlec, A. (2019). Engineering of lactic acid bacteria for delivery of therapeutic proteins and peptides. Appl. Microbiol. Biotechnol. 103, 2053-2066. doi: 10.1007/s00253-019-09628-y

Plavec, T. V., Štrukelj, B., and Berlec, A. (2019). Screening for new surface anchoring domains for Lactococcus lactis. Front. Microbiol. 10:1879. doi: $10.3389 /$ fmicb.2019.01879

Pontes, D., Innocentin, S., Del Carmen, S., Almeida, J. F., Leblanc, J.-G., De Moreno De Leblanc, A., et al. (2012). Production of fibronectin binding protein A at the surface of Lactococcus lactis increases plasmid transfer in vitro and in vivo. PLoS ONE 7:e44892. doi: 10.1371/journal.pone.0044892

Raha, A. R., Varma, N. R. S., Yusoff, K., Ross, E., and Foo, H. L. (2005). Cell surface display system for Lactococcus lactis: a novel development for oral vaccine. Appl. Microbiol. Biotechnol. 68, 75-81. doi: 10.1007/s00253-004-1851-8

Ramos, P. E., Cerqueira, M. A., Teixeira, J. A., and Vicente, A. A. (2018). Physiological protection of probiotic microcapsules by coatings. Crit. Rev. Food Sci. Nutrit. 58, 1864-1877. doi: 10.1080/10408398.2017.1289148

Ravnikar, M., Strukelj, B., Obermajer, N., Lunder, M., and Berlec, A. (2010). Engineered lactic acid bacterium Lactococcus lactis capable of binding antibodies and tumor necrosis factor alpha. Appl. Environ. Microbiol. 76, 6928-6932. doi: 10.1128/AEM.00190-10

Robert, X., and Gouet, P. (2014). Deciphering key features in protein structures with the new ENDscript server. Nuc. Acids Res. 42, W320-W324. doi: 10.1093/nar/gku316

Rockberg, J., Löfblom, J., Hjelm, B., Uhlén, M., and Ståhl, S. (2008). Epitope mapping of antibodies using bacterial surface display. Nat. Methods 5, 1039-1045. doi: $10.1038 /$ nmeth. 1272

Rolain, T., Bernard, E., Courtin, P., Bron, P. A., Kleerebezem, M., ChapotChartier, M.-P., et al. (2012). Identification of key peptidoglycan hydrolases for morphogenesis, autolysis, and peptidoglycan composition of Lactobacillus plantarum WCFS1. Microb. Cell Fact. 11:137. doi: 10.1186/1475-2859-11-137

Seguí, J., Gironella, M., Sans, M., Granell, S., Gil, F., Gimeno, M., et al. (2004). Superoxide dismutase ameliorates TNBS-induced colitis by reducing oxidative stress, adhesion molecule expression, and leukocyte recruitment into the inflamed intestine. J. Leukocyte Biol. 76, 537-544. doi: 10.1189/jlb.0304196

Simşek, Ö. (2014). Nisin production in a chitin-including continuous fermentation system with Lactococcus lactis displaying a cell wall chitin-binding domain. J. Indust. Microbiol. Biotechnol. 41, 535-543. doi: 10.1007/s10295-013-1388-x

Škrlec, K., Pucer, J. A., Rogelj, B., Štrukelj, B., and Berlec, A. (2017). Evasindisplaying lactic acid bacteria bind different chemokines and neutralize CXCL8 production in Caco-2 cells. Microb. Biotechnol. 10, 1732-1743. doi: $10.1111 / 1751-7915.12781$

Skrlec, K., Rucman, R., Jarc, E., Sikiric, P., Svajger, U., Petan, T., et al. (2018). Engineering recombinant Lactococcus lactis as a delivery vehicle for BPC157 peptide with antioxidant activities. Appl. Microbiol. Biotechnol. 102, 10103-10117. doi: 10.1007/s00253-018-9333-6

Steen, A., Buist, G., Horsburgh, G. J., Venema, G., Kuipers, O. P., Foster, S. J., et al. (2005). AcmA of Lactococcus lactis is an $\mathrm{N}$-acetylglucosaminidase with an optimal number of LysM domains for proper functioning. FEBS J. 272, 2854-2868. doi: 10.1111/j.1742-4658.2005.04706.x

Stern, J., Moraï, S., Ben-David, Y., Salama, R., Shamshoum, M., Lamed, R., et al. (2018). Assembly of synthetic functional cellulosomal structures onto the cell surface of Lactobacillus plantarum, a potent member of the gut microbiome. Appl. Environ. Microbiol. 84:e00282-18. doi: 10.1128/AEM.0 $0282-18$

Tang, X., Liang, B., Yi, T., Manco, G., Ilariapalchetti, and Liu, A. (2014). Cell surface display of organophosphorus hydrolase for sensitive spectrophotometric detection of p-nitrophenol substituted organophosphates. Enzyme Microb. Technol. 55, 107-112. doi: 10.1016/j.enzmictec.2013.10.006

Tomosugi, W., Matsuda, T., Tani, T., Nemoto, T., Kotera, I., Saito, K., et al. (2009). An ultramarine fluorescent protein with increased photostability and pH insensitivity. Nat. Methods 6, 351-353. doi: 10.1038/nmeth.1317

Walter, J. (2008). Ecological role of lactobacilli in the gastrointestinal tract: implications for fundamental and biomedical research. Appl. Environ. Microbiol. 74:4985. doi: 10.1128/AEM.00753-08 
Watterlot, L., Rochat, T., Sokol, H., Cherbuy, C., Bouloufa, I., Lefevre, F., et al. (2010). Intragastric administration of a superoxide dismutase-producing recombinant Lactobacillus casei BL23 strain attenuates DSS colitis in mice. Int. J. Food Microbiol. 144, 35-41. doi: 10.1016/j.ijfoodmicro.2010.03.037

Wieczorek, A. S., and Martin, V. J. (2012). Effects of synthetic cohesincontaining scaffold protein architecture on binding dockerin-enzyme fusions on the surface of Lactococcus lactis. Microb. Cell Fact. 11:160. doi: 10.1186/1475-2859-11-160

Xu, W., Huang, M., Zhang, Y., Yi, X., Dong, W., Gao, X., et al. (2011). Novel surface display system for heterogonous proteins on Lactobacillus plantarum. Lett. Appl. Microbiol. 53, 641-648. doi: 10.1111/j.1472-765X.2011.03160.x

Yin, S., Zhu, H., Shen, M., Li, G., Lu, S., Zhao, Y., et al. (2018). Surface display of heterologous $\beta$-galactosidase in food-grade recombinant Lactococcus lactis. Curr. Microbiol. 75, 1362-1371. doi: 10.1007/s00284-018$1531-\mathrm{z}$
Zadravec, P., Mavrič, A., Bogovič Matijasic, B., Štrukelj, B., and Berlec, A. (2014). Engineering BmpA as a carrier for surface display of IgG-binding domain on Lactococcus lactis. Protein Eng. Des. Sel. 27, 21-27. doi: 10.1093/protein/ gzt059

Conflict of Interest: The authors declare that the research was conducted in the absence of any commercial or financial relationships that could be construed as a potential conflict of interest.

Copyright $\odot 2021$ Tay, Lim and Ow. This is an open-access article distributed under the terms of the Creative Commons Attribution License (CC BY). The use, distribution or reproduction in other forums is permitted, provided the original author(s) and the copyright owner(s) are credited and that the original publication in this journal is cited, in accordance with accepted academic practice. No use, distribution or reproduction is permitted which does not comply with these terms. 